\title{
The EU and the East-West Paradox
}

\author{
The Case of Greece and Turkey
}

Hercules Millas

\begin{abstract}
In both Greece and Turkey anti-western discourse is widespread. On the one hand both societies perceive themselves as European, but at the same time they criticize the 'West' as religiously or culturally different from 'us', being prejudiced against 'us', siding with our rivals, as hypocritical, cruel or imperialist. These stereotypes have real or imaginary historical dimensions, but they also relate to recent political controversies. While the rationalisations of these images are not identical in the two countries, the contradictory end results are quite similar. While they criticize the West, neither the Greeks nor the Turks associate themselves with the 'East' or any 'eastern' country. When all these ambiguities are taken into consideration one may conclude that the anti-West/Europe discourse is used as a political means to voice complaints and demands: 'You do not accept a cut on our debt', or 'You do not accept us in the EU'. These are accusations that show the 'self' as a victim. They also show a national identity in anguish: 'We are being treated unjustly, humiliated, etc'. This discourse also operates indirectly as a means of comparison with the 'developed Western' countries, stating ones own moral and cultural superiority.
\end{abstract}

On January 9, 2017 the president of Turkey R. T. Erdoğan accused the 'West' of being hypocritical. In his speech to a group of Turkish governors in Ankara he said that even if one leaves aside some negative practices of the West such as "their inhuman treatment towards the refugees and their lack of sensitivity when children, women and old people were killed", ${ }^{1}$ still the hypocrisy is seen when one considers how the West reacts when a terrorist action takes place in the West and how it remains indifferent when a similar action takes place in Turkey. He also inferred that the 'West' is against Turkey.

Accusations against the 'West' are common in Greece, too, especially after the economic crisis of 2010. The president of Greece Prokopis Pavlopoulos,

1 Erdogan (2017). All translations from Turkish and Greek sources are by the author.

(C) HERCUlES Millas, 2021 | DOI:10.1163/9789004436107_009

This is an open access chapter distributed under the terms of the CC BY-NC-ND 4.0 license.

Hercules Millas - 9789004436107 Downloaded from Brill.com@4/26/2023 01:21:20PM 
for example, in 2013 called the agreement with the EU and IMF which aimed at coping with the economic crisis in Greece "a dishonourable pitchfork to which the government gave in". ${ }^{2}$ The Union of Judges and Public Prosecutors in February 2016 unanimously declared that "the Greeks should stop being the economic guinea pigs of Europe". ${ }^{3}$ Vassiliki Thanou, the head of the Supreme Court sent a letter to her counterparts in the European Union in July 2015 stating that the Greek people are not responsible for the state debt, but rather the EU governments and the IMF, and that the creditors "should not seek the extermination of the debtor."

However, when such Turkish and Greek accusations are put side by side a paradox comes into view. In an article in a Greek blog titled The hypocrisy of the West should end the EU and the USA are criticised for not taking a clear stand against R.T. Erdoğan's authoritarian policies of the last few years. So the 'West' is seen as hypocritical for not being pro-Turkey in Turkey; but it is seen as hypocritical for being pro-Turkey in Greece. ${ }^{5}$ That Greece is 'the spoiled child of the West' because they are seen as the heirs of Ancient Greece is an old and established term in Turkey; in stark contrast to Greek perceptions of anti-Greek bias in the 'West'. In other words, both sides perceive the 'West' as unjustly siding with 'our opponent' - but for different and contradictory reasons.

When national discourses and ethnotypes are studied comparatively they may prove to exhibit remarkable similarities between sharply distinguished groups. Conversely, 'universal' traits turn out to be asymmetrically ascribed across borders or between groups. In what follows, I will try to present some peculiarities of Greek and Turkish 'Occidentalism', i.e., the way the so-called 'West' is understood in both countries' use of images, stereotypes and contradictions.

\section{Anti-Westernism in Numbers and in Meaning}

Opinion polls show that in both Greece and Turkey anti-western feelings run high. According to the Pew Research Center findings, in 2014 the top six countries that are critical of the US are Egypt (85\%), Jordan (85\%), Turkey $(73 \%)$, Russia (\%71), Palestine (66\%) and Greece (63\%). Pakistan and Lebanon

2 See Kroustalli (2017). The declaration was made in September 2013, before Pavlopoulos was elected president.

3 ToVima (2016).

4 Iefimerida (2015).

5 See Voria.gr (2016). 
follow. ${ }^{6}$ Two aspects are of interest: a) Turkey and Greece are allies of the US in NATO, but still they emerge as top opponents; b) Among the top eight 'critics' are only Muslim and Orthodox Christian countries or populations. Conversely, among the top eight 'US fans' - the Philippines, Israel, South Korea, Kenya, El Salvador, Italy, Ghana and Vietnam - there are no Muslim or Orthodox Christian countries.

According to the Greek Palmos Analysis' opinion poll, at the end of 2016 $84 \%$ of Greeks believe that the EU is moving in the wrong direction and only half of the participants of this survey are in favour of staying within the EU.7 An opinion poll in Turkey 2015 showed that the wish to join the EU among the Turks - which in 2005 was of the order of $70 \%$ - during the last four years decreased to a low of $20-35 \% .{ }^{8}$ According to a more recent opinion survey in Turkey $68 \%$ of Turks want to terminate the negotiations for the country's entrance to the EU, believing that the westerners are not "sincere" $(82 \%)$ and do not want Turkey entering the EU because "the Turks are Muslims" (6o\%). They also believe that western discourse related to Turkey is "humiliating". ${ }^{9}$

These complaints go beyond criticising the doings of the 'West' and of the 'westerners'; their actions are presented as being motivated by ill intentions and/or the problematic 'character' of the 'West'. Disagreement thus moves into the emotional, even phobic register of temperamental ill-will imputed to a 'West' perceived as unjustly biased 'against us.'10

In the few examples referred to above, for example, the anti-west utterances impute the West to be inhuman and insensitive when facing the unhappiness of the world; the West is hypocritical, has a wicked 'character', imposes dishonourable sanctions on 'us', has turned 'us' to guinea pigs, the policy of the West signals our 'extermination'. These allegations and the words in which they are couched show that the grievances are part of a group opposition rather than a policy disagreement. The conflict is sparked by the incompatibility between these groups' different ethical values, perceptions of justice, opposing worldviews and dissimilar cultures.

In Greece and in Turkey the 'West' features in many historical narratives, in politics, in textbooks, the media, literary texts, the arts and even in books for children. There is a substantial bibliography related to negative Western

6 See Question 15a of the Pew Global Studies survey 2014 (2014). This favourability distribution shifted slightly following the election of Donald Trump as US-President.

$7 \quad$ Palmos Analysis (2016).

8 See Haber 3 (2015).

9 Internet Haber (2016).

10 For 'our image' vis-à-vis of 'how the Other sees Us' (i. e., meta-image) see Leerssen (2016). 
images of the East; ${ }^{11}$ such orientalism is encountered both in Greece and in Turkey. But the image of the West in these countries - Levantine Occidentalism - deserves closer study. ${ }^{12}$ I will give some limited samples to show the range of this anti-western discourse. The discourse itself involves the following imputations and characterisations, digested here from the various sources listed in the bibliography:

- The West is a monolithic, uniform, homogeneous entity which can be subsumed under this singular appellation;

- The West has no specific geographic boundary; it may be the EU, the USA, Europe in general, the western Europe of the Renaissance and the Industrial Revolution, and may or may not include the Balkans;

- It is religiously different. Among Greek orthodox spectants it is seen as Catholic and Protestant, among Turkish Muslims as Christian. These religious differences are imagined in a historical context, too. Greeks recall the Great Schism of 1054, Turks the wars between the Ottomans and the Europeans. Both 'remember' the crusades.

- Besides the religious difference, there is an adversarial perception of the West as pursuing either its national interests as great powers, or economic exploitation as colonial hegemons.

- As such, the West may be suspected of being in league with other, unspecified enemies.

- The West is prejudiced against 'us' and harbouring negative stereotypes of 'us': Turks feel they are perceived as uncivilised, Greeks feel they are perceived as lazy and as unworthy descendants of a glorious ancestry. ${ }^{13}$

- Temperamentally, the self-interest of the ruthless and cynical West is opposed to the positive characterisation reserved for the 'We'-group: humane, hospitable, righteous, sensible, honest, honourable.

The East-West issue plays an important part in both Greek and Turkish historiography. In the Greek's case the East-West controversy became a major issue

11 See Said (1994), which is well known, especially in Turkey. Also see Todorova (2009) where the perception in the Balkans is discussed.

12 See, for example Carrier (1995) and Buruma, Margalit (2005).

13 On these meta-images - how the Other sees us -, see Millas (2001); Millas (2005a); Millas (2005b). 
during the years of the Greek War of Independence of 1821-29. ${ }^{14}$ The revolutionaries, mostly diaspora intellectuals based in various cities of Western Europe and influenced by the ideals of the French Revolution, promoted the 'western' ideas. Conservative Greeks, mostly close to the patriarchate of Constantinople and living within the Ottoman state, anathematised these Enlightenment modernizers, such as Paris-based Adamantios Korais (1748-1833), and advised prudent adherence to 'paternal ideals' as opposed to Western innovation. ${ }^{15}$

With the establishment of the modern Greek nation-state (1830) a modus vivendi was accomplished between the two sides of this controversy. ${ }^{16}$ The republican discourse was silenced and a Holy Alliance (between the throne and the altar) was secured. A straightforward national myth dominated nineteenth-century historiography: The Greeks, descendants of the glorious ancient Hellenes, had after many centuries under Ottoman rule thrown of the tyrannical 'Turkish yoke' and regained their independence. Greek-Orthodox Christianity, the basic belief of most of the Greek cultural community, was dexterously integrated into the ancient heritage. Spiridon Zambelios coined the concept of 'Helleno-Christianity' in the mid-nineteenth century to express this national harmony, and religion was thus 'ethnicised' during this nation-building phase. Greekness was closely associated with religion, and in particular with the Greek Orthodox Church and its legacy. Thus the two historicist repertoires, secular Antiquity and the Orthodox Christian heritage, have coexisted in an oblique West-East polarity until the present day.

In recent decades a number of researchers emphasising the contribution of the Greek Orthodox Church seem to have reproduced the old opposition between East and West and between believers and unbelievers. This religion-related movement in Greece is known as 'New Orthodoxy'. The following quotation from G. Metallinos, a well-educated historian and priest, can serve as an illustration. I have added some clarifying comments.

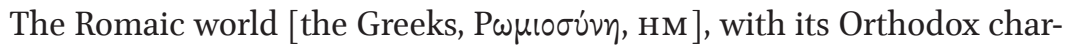
acter and as the heir of Hellenism, had always been irksome to Frankish Europe [...]. The West had a permanent aim: the destruction of the Romaic civilization. The Frankish attempt in 1204 [to capture Constantinople, $\mathrm{HM}$ ] failed, as it failed to Latinize the Orthodox East. The blow of 1453 [the capture of Constantinople by the Ottomans, HM] was not strong enough to kill the Romaic world either. During the years of slavery

\footnotetext{
14 See Millas (2008).

15 See Dimaras (1985).

16 For this and the following see Grigoriadis (2013).
} 
[Ottoman rule, $\mathrm{HM}$ ] all the westerners, i.e., those tied to the Pope and the Protestants, the missionaries and all the western political propaganda were defeated. So Romiosini could experience its resurrection again. [...] The political aim of Europe [i.e. non-Orthodox Europe, HM] was not only the partition of the Ottoman Empire but also to obstruct the expectation that it would give way to a renewed Greek and Orthodox empire. ${ }^{17}$

The same author represents Western Enlightenment and related ideas as foreign ideals that did not normally develop within Greek society and were contrary to the Greek tradition. He also asserts that the Western Powers (England, France, Holland etc.) eventually sided with the Turks, seeking their own self-interests and not helping Greece. ${ }^{18}$

Hristos Yiannaras is probably the most well-known representative of the New-Orthodoxy movement. According to him the East and the West have always been two different worlds. Unlike the East, the West is materialist and selfishly individualist and has strayed from true Christianity. "Actually, in the West we have anti-Christianity and hatred for the Greeks". ${ }^{19}$ The Western world is hedonistic, corrupt, guilty of barbarities like the Inquisition, Auschwitz, Hiroshima, and more recently the massacres of Serbs. The West is hypocritical and on the side of the enemy of Greece, namely Turkey; conversely, the Orthodox 'personality' of the Greeks is superior to the West. ${ }^{20}$

In Greece the political spectrum accommodates anti-western groups besides the New-Orthodoxy. The extreme right-wing Hrisi Avgi (Golden Dawn) which has eighteen deputies in parliament (out of a total of 300 members) is one of them. Their opposition to the 'West' is not based on religion but on political and racial considerations. Still, there is an indirect relation with the New-Orthodoxy as it is apparent from their references to its theoreticians such as Yiannaras and Metallinos. ${ }^{21}$ On the official website of Hrisi Avgi, for example, in an article related to the ideology of this movement, we read that the West always fought the Greeks by means of Jews:

As the professor of philosophy Hristos Yiannaras says [...] the Jews (like Marx, Freud, Einstein, Kafka, Steinberg, Woody Allen, Claude Lévi-

17 Metallinos (1988), p. 175. For the metaphorical 'resurrection' of the Greek nation-state, alluded to in this passage, see Millas (2006), pp. 47-6o.

18 See Metallinos (1988), pp. 151, 94.

19 Hristos Yiannaras as quoted by Heraclides (2001), p. 84.

20 See Heraclides (2001), p. $86 f$.

21 For a critical presentation of Yiannaras see Heraclides (2001). 
Strauss, etc.) were the spokesmen of the civilization of Western Europe but actually they did not create any original thinking. They only copied whatever the Greeks have accomplished and thus they promoted the Jews. Instead of Plato they created the Jewish philosopher Aristobulus of Alexandria who claimed that Plato had read the text of Moses; instead of Kant, the new-kantianist Hermann Cohen; instead of Epicurus, Marx; instead of Constantin Carathéodory, Einstein, etc. So Greece says that it belongs to the West, but the West plans its extinction. ${ }^{22}$

The communist and socialist Left often uses an anti-western discourse based on ideological principles couched in Marxist terminology. ${ }^{23}$ The 'West' (USA and EU) is generally perceived as a capitalist and imperialist block. Thus we find this statement on the official website of the Greek Communist Party KKE:

The jihadists are powers that were supported and armed by the USA, NATO and the EU in order to implement their plans in Iraq, Syria and Libya and today they are used as a pretext for new interventions and wars $[\ldots]$. The Greek people must fight so that Greece is not part of NATO and other similar organisations which cause the bloodshed of nations in the interest of capital. ${ }^{24}$

Syriza followers use a less strident wording but the attitude is not much different. On the website of Syriza in an article on the island of Zakinthos titled The heart-breaking nightfall of the West we read evaluations such as these in relation to the Arabic Spring and the refugee crisis:

From the beginning the West showed first its foolishness and then its cruelty. Naturally, this is not the first time that the West shows its cruelty. In 1939 when 937 Jew refugees ran away from Hitler and were going up and down in the Atlantic neither USA nor Canada accepted them. [...] And now the civilised EU which claims that it has abolished its borders,

\footnotetext{
22 Karaiskos (2016).

23 The left in Greece is presently composed of the Greek Communist Party (KKE) with 15 deputies in parliament, and Syriza (Radical Left Coalition) which is in power at present with 145 deputies. There are about ten small leftist groups, which participate in the general elections but are not represented in parliament. All together the left composes $41 \%$ of the parliament and about half of the electoral public.

24 Katsaros (2014). Official declaration of KKE on 25.9.2014, in connection with the declaration of the Greek Ministry Foreign Affairs on fighting the Islamic State.
} 
re-imposes them in the cruellest way. [...] The cynical arrangement between the EU and the regime of T. Erdoğan on the issue of the refugees is an example of the neo-colonialist policy of the EU. [...] Often the Western type of haughtiness haunts the so-called backward Arabs. ${ }^{25}$

Again, critiques of the 'West' go beyond the denunciation of actual or imagined misdeeds, but explain those with an intrinsic 'character', the unchanging essence of the 'West'. The West was in the past as it is now, and new misdeeds are reiterations of older ones. Accusations of this kind are commonplaces among many followers of the left ideology.

The 'East-West issue' - as the relations of Turkey and the Turks with the 'West' are called: Doğu-Batı sorunsalı - dominates all aspects (historical, social, cultural) of Turkish society over the last two hundred years. The 'East-West issue' crops up in any major social topic; largely because the most vital social changes were initiated, caused or influenced by the country's relations to the 'West'.

Starting from the time of Sultans Selim III (1761-1808) and especially Mahmut II (1785-1839) the Ottoman Empire initiated a series of reforms of 'Westernisation' (later known as Batılılaşma). ${ }^{26}$ The modernisation of the state in order to cope with the 'West' had appeared as a necessity after a series of military defeats against the European powers. The changes were many and covered various fields. ${ }^{27}$ Selim created a new treasury, opened a navigation school and attended to printing and to the circulation of Western translations. Mahmut was much more radical. He abolished the Janissary Corps in 1826, establishing a western type Ottoman Army. In 1831 he founded an official gazette, Takvim-i Vekayi (Calendar of Events), the first newspaper to be published in the Ottoman-Turkish language. Instead of a vizier, a prime-ministerial office was established, and a new bureaucracy appeared with western-type ministers. New schools, mostly military academies were established. Young Turks were sent to Europe for studies.

Those innovations, however, were limited. The state aimed at benefitting from Europe's scientific knowledge insofar as this could be done without transplanting European culture into the empire. In 1839 the Tanzimat era started

\footnotetext{
25 Karaiskos, Thanasis (2016).

26 See Zürcher (2004).

27 See Hanioğlu (2008), pp. 55-108.
} 
establishing equality between Muslims and non-Muslims. These reforms known as Hatt-1 Humayun were reaffirmed in 1856 and rendered necessary because of Muslim reluctance to grant equality to the non-Muslim millets, i.e. to the citizens of the Empire. At this point a class bifurcation became clear: The Westernisation process became a movement of the cities and of the elite of the Muslim population. From dresses to everyday life a western way started to be accepted in the Empire by the Muslim elite population. However, at the popular level, in the agrarian and mostly Anatolian section of society the reforms met with reservations.

The most important counter voice was that of the former bureaucrats labelled as the Young Ottomans. They criticised Tanzimat as 'capitulation to the European dictates.' Established as a secret society in 1865 by a group of intellectuals such as Şinasi, Namık Kemal, Ali Suavi and Ziya Pasha, the Young Ottomans agreed that a new constitutional government should continue to be somehow rooted in Islam, emphasising "the continuing and essential validity of Islam as the basis of the Ottoman political culture."28 The acceptance of Western laws instead of the Sharia was considered tyranny, and the example of Europe should be limited to scientific and industrial progress. ${ }^{29}$

This dualism of modernisation and westernisation versus local, national and Islamic tradition started a struggle that is still not resolved. About forty years after the Young Ottomans, another reformist group, the Young Turks, triggered a revolution in 1908, the beginning of a Constitutional Era. With the Young Turks, nationalism emerged among Turks and Ottoman Muslims. This nationalism was fanned by the Balkan Wars (1912-14), the First World War (which ended in defeat for the Ottoman State), a post-1919 invasion by Entente powers, and a War of Independence (1919-22). During these developments the negative image of the West evolved further.

On the surface, the ambiguity vis-à-vis the 'West' as what to take and what to refuse seemed to continue unabated. Ziya Gökalp, for example, the theoretician on ideological matters both of the Young-Turks and of the Kemalist new Turkish Republic, repeated the formula: the technology of the West should be adopted, while at the same time protecting and strengthening the nation's characteristics. ${ }^{30}$ In fact, Gökalp in 1918 made a clear distinction between culture and civilisation (hars and medeniyet). Civilisation is what the upper classes share worldwide; culture is what characterizes each group of people

\footnotetext{
$28 \quad$ Bora (2002), p. 253 .

29 The Westernisation debates were very complex and full of ideological nuances. See, for example, Bora (2002). Here I limit myself to a broad outline. 
separately, and what secures the existence of the nation. ${ }^{31}$ According to Gökalp the culture of a nation is of greater importance since it preserves its identity, its values and its character. He was very much in favour of the preservation of what he saw as genuine Turkish-Islamic culture. In essence this attitude, as articulated by the Young Turks and Gökalp, has remained in force until our days. The official Turkish position was and still is that Turkey is to be part of the West, but naturally preserving what it sees as its Turkish national identity.

However, an important ideological change vis-à-vis the 'West' occurred with the rise of Turkish nationalism starting in the year 1910. This change, which assigned new negative characteristics to the 'West', was not actually noticed and adequately understood because it was seen and internalised as a given reality rather than as an attitude or image. Apart from being advanced, rich, strong, cultivated, different and a probable threat the West started to be associated with negative ethical characteristics; this was a new phenomenon. This change is best seen in the development of the Turkish novel. Until 1910 the leading novelists of the Ottoman period aimed their criticism not at the 'West' itself, but only at the Turks and Muslims who imitated and tried to look like westerners. There is, however, a sudden change after 1910 around the time when the nationalist Young-Turks came to power. A new generation of writers appeared, presenting a new image of the westerners: negative personalities such as violent and dishonest men or shameless women seducing and betraying the Turkish characters. The dishonest and expansionist 'West' as a whole came to be presented as the cause of many national sufferings and as a threat to Turkey. That was the message of hundreds of literary texts of this kind. ${ }^{32}$

Naturally the Turkish novel and Turkish literature overall does not consist only of this kind of stories. The general perception of the West, however, remained that of a political enemy (among nationalists), a moral threat (among Islamists) or a colonial/imperial hegemon (among the Left). The East-West metaphor governed it all. The 'West' is spiritually unsound, it is individualistic and selfish, modern but corrupted, indulgently permissive to the detriment of sound ethical traditions and values. The belief that the technology of the West is needed, but that its culture is noxious continues to be widely heard. The following illustrative examples are from two recent articles, published in the Turkish media, the first condemning the West, the second analysing the situation:

$31 \quad$ See Ünüvar (2002), pp. 28-35.

32 See Millas (2001); Millas (2005a); Millas (2005b). 
There is no doubt that the modern version of anti-westernism is expressed as anti-Americanism [...]. This is so because the USA is the leader of the West. [...] The reason of the anti-western movement is the expansionist policy of the West that continues from the oldest times of history until today $[\ldots]$. The west has double standards $[\ldots]$ and has a negative image of Islam. ${ }^{33}$

The perception of the West has completely deteriorated lately in Turkey. A great section of the people believes that the West is a demon that has collaborated with the powers that tried the coup d'état [on 15 July $2016, \mathrm{HM}]$ and that wants to break the country apart. The West is seen as a single homogeneous body and as a source of ills. As a consequence the people do not want to listen to any criticism that comes from the West, even if this is justified. On the other hand the number of those who want new alliances with any power apart from the West is increasing. ${ }^{34}$

\section{$4 \quad$ Contradictions and Elisions}

There are various contradictions and elisions in the Greek and Turkish positions vis-à-vis the West and/or Europe:

1. Both claim that they are part of Europe. Especially many Greeks believe Europe without Greece is an oxymoron since even the name of the continent is Greek and the 'spirit' of modern Europe is based on the revival of Ancient Greece through the Renaissance. In Turkey the official and widely supported view is that the Turks have become part of the history of Europe since the time of Sultan Mehmet II (1432-81) and Sultan Süleyman (1494-1566), and that they have always been in touch with the developments of the West. However, when the Greeks and Turks use the terms 'Europe' and 'West' they also mean a number of countries in the west which are different from them. Europe is spoken of both as an extension of, and as an opposition to their own national identity.

2. The geographic use of the word 'West' raises the anticipation of its antonym East. But while denouncing the West, neither Greeks nor Turks associate themselves with the 'East' or any 'eastern' country. Indeed they would reject, sometimes indignantly so, a characterisation as 'oriental'. Turks resist being associated with Iran and other (Arabic) 'eastern' coun-

\footnotetext{
33 Altun (2017).
}

34 Coşkun (2016). 
tries. Greeks by the same token refuse to be associated with an 'eastern' country like Turkey, whom in fact they are intransigently set against. Thus the very idea of an 'East versus West' discourse collapses in on itself. For Greece, Turkey is East and Italy is West. For Turkey, Greece is West and Syria and Iran are East. Neither considers itself Eastern. While both countries see a West and an East, they do not see themselves as belonging to either of these two categories. Where do they belong, then? An acceptable answer would be that they see themselves to be simply 'anti-Westerners'. Or both, but separately, at the centre of the world.

3. There is a subsidiary East-West conflict between Greece and Turkey. Greeks believe that they are 'Europeans' when they compare themselves with 'eastern' Turkey; and Turks perceive Greece to be part of a 'European conspiracy' when they envisage future threats from 'western powers'. This ambiguity exists even though Greece and Turkey are allies within NATO. Thus both countries, both positioned against both West and East, are also positioned against each other within an East-West context.

4. There is an unresolved ambivalence concerning the pros and cons of Europe. Turkish reforms starting from the early nineteenth century were initiated under the banner of 'westernisation', but simultaneously triggering anxiety at the baleful influence of European 'culture' and lifestyle. Greece, too, followed 'western' political models and 'way of life', but to a considerable extent also stressing the importance of preserving the national character of Greek society. Is it desirable or is it harmful to be like the West and Europe? The question remains unresolved. The West is supposed to be against 'our culture', but it is still followed and imitated.

5. There is an unresolved ambivalence concerning the political and military relationship with the 'West'. Both in Greece and in Turkey it is widely believed that the 'West' is favouring the Other, 'our enemy', Turkey and Greece, respectively. Greeks accuse the West of selfishly reneging on its duty to stand by its ally, Turks accuse the West of anti-Islamist favouritism for Greece.

6. Both sides explain and justify their anti-Western/anti-European positions with a recourse to history. The problem with the historical argument is that, while the examples of past enmity are real, they are selectively chosen and partially presented. Instances of European support are passed over in silence, such as the European support for the Greek War of Independence in the 1820s, French and Italian neutrality in support of the Turkish War of Independence in 1923 and NATO support against the USSR in the Cold War. Instead, history is skewed to blame the Other. 
7. The negative aspects of the 'West' are raised or dropped as suits the occasion. When bilateral relations are harmonious, the past and the 'character' of the Other are shown in a positive light, or neutrally. When problems occur the accusatory repertoire is re-activated. These ups and downs are themselves 'explained' by 'history' too: a historical 'friendship' or an 'enmity' is recalled according to the needs of the moment. The 'character' of Europe reflects the political attitudes of the moment. The image of Europe was positive during the years 2002-2008 in Turkey but turned negative later; and likewise the Greeks suddenly remembered the 'hypocrisy' of the West and of the Germans when they were asked to pay back state loans.

8. The discourse is often at variance with actual events. The theme that the 'West' is against Turkey because of Christian prejudices of the Christians vis-à-vis Muslims was formulated at a time when Muslims in the Middle East were involved in fierce internecine and religiously motivated strife. This intra-Islamic clash is much more cruel and bloody than anything that is denounced in the relationship between the so-called East and West. Similarly, tensions between Sunni and Alevite Muslims within Turkey are much more pronounced than any real or imagined East-West controversy.

All these contradictions signal the necessity not to take the anti-European discourse at its face value. The terms 'West' and 'Europe' do not have definite meanings, are volatile and emotive terms, understood differently by different people in Greece and Turkey; and their meanings change in time, too, contingently. They serve a purpose, though, and that is why they exist. The most common use of these terms is to blame the Other: to a power that is seen as an enemy, as a rival, as a threat.

The terms 'Europe' and 'West' are preferred to specific names of countries by virtue of their very vagueness. A term that evokes a large number of opponents suggests, on the one hand, that the adversary is mighty, while, on the other hand, 'we' too can stand up to them. Rhetorically, 'Europe is against us' is more effective than 'Germany is against us'. The use of a vague term like 'West' is also a diplomatic way to state complaints and accusations indirectly and without escalating a controversy with a specific country or group of countries. 'Westerners are hypocrites' is more allowable than 'the French are hypocrites.'

The terms Europe and the West recall and reactivate the past. They remind 'us' of our old historical enemies (be they real or constructed), and remind the Other of his ancient guilt such as the colonial past, and frame the present in 
the cognitive comfort zone of century-long stereotypes and prejudices, dating back to old religious conflicts.

This discourse has all the hallmarks of classical nationalist ideology and argumentation: It is xenophobic, proclaims one's own moral superiority over inferior foreigners, frames modern relations in the putatively timeless essence of eternal national characters, and imputes, by an act of projection, whatever enmity is involved wholly to the Other's malice.

When all these contradictions and ambiguities are taken into consideration, one may be tempted to conclude that the anti-Western/anti-European discourse is used tactically as a political rhetoric: to voice complaints and demands. 'You do not accept a cut on our debt', or 'You do not accept us in the EU'. Such accusations bespeak a victimised self-image and a national identity in anguish: 'We are being treated unjustly, humiliated', etc. Used opportunistically, either to demand 'understanding' and 'compassion' for 'our shortcomings' and some other times to ask for help, this rhetoric operates as a defense mechanism against criticism - saying 'but you have done worse things' - and as a justification for demands - saying 'you owe something to us; you have to make amends.' All anti-Western discourses indirectly and eventually express a request.

There is also another way to account for this aggrieved sense of Eastern victimhood. In the less developed (industrialised and democratisedised) countries outside North-Western Europe, capitalism was introduced as an 'imported' foreign phenomenon. Anti-capitalist reactions, which in Western Europe found outlets in the form of Romanticism and socialism, could in South-Eastern Europe take the form of resistance against a foreign, 'Western/ European' way of life. Indeed all anti-Western criticism is characterised by nostalgic conservatism and an emphasis on wholesome home-grown traditions. Anti-Western discourse in Greece and Turkey corresponds - by analogy - to the conservative (anti-capitalist) discourse of the industrialised countries of the nineteenth century.

This 'Eastern reaction' to modernism is reflected in the different socialist discourses, too. In the 'West' the fight for socialism is expressed as an anti-capitalist movement; in Greece and Turkey this reaction is mostly directed against 'imperialism'. In other words, what in the 'West' is experienced as class grievances is voiced in Greece and Turkey as anti-Western grievances.

Anti-western nationalism is somehow different from the original nationalism of the west. First, it is late by two or three centuries. Second, the modernisation 
process in countries that invoke it is less advanced than in the early nationalist countries. This economic difference creates the self-image of being non-Western (and non-Eastern as well) and having a Balkan and maybe a Near-eastern identity; or an identity associated with a non-Western religious tradition such as Islam and Orthodoxy.

Differences in religion and culture do not in themselves create the tension. The tension is created by rising nationalism and the attendant antagonism between Self and Other. In Greece and Turkey, anti-western discourse is almost always associated with emerging or current nationalist ideals.

Naturally (and fortunately) not all Greeks and Turks share the same ideas and attitudes. One encounters firmly pro-European views and critiques of phobic nationalism. To interpret anti-westernism in an essentialist manner as a 'clash of civilisations' and to underestimate its ideological (nationalist) nature may operate as self-fulfilling prophecy: The beliefs and the perceptions may turn into real actions and situations.

Apart from our image of the Other, the image that we have of the Other's image vis-à-vis us is of paramount importance in the case of mutual antagonisms as with Greeks and Turks. They are very keen to see how the Other sees them; and they develop a new image: the meta-image of how the Other sees them. ${ }^{35}$ This image at present is negative. The Greeks believe that 'Westerners' consider them lazy, extravagant, easy going and worse: unworthy and insufficiently civilised descendants of their ancient ancestors. Turks also think that the image of the Europeans about them is very negative: Easterners, aliens to European values and culture, historically and religiously associated with despotism and terrorism. Such meta-images are deeply hostile to the Other while imputing that same hostility to the Other; it cannot but be detrimental to the relations between nations. To control accusatory discourses and to recognize whatever is good in the Other would be a more helpful and constructive approach for all parties concerned.

\section{Bibliography}

Altun, Fahrettin (2017). "Batı Karşıtlı̆̆ı" Niçin Anlamlıdır?' [Why is anti-westernism meaninful?], 26. January, Yeni Şafak. https://www.sabah.com.tr/yazarlar/fahrettinaltun/ 2015/o1/26/bati-karsitligi-nicin-anlamlidir [accessed 11.05.2019].

For the concept of meta-image see Leerssen (2016). 
Bora, Tanıl (2002). 'Millıyetçi-Muhafazakâr ve İslamcı Düşünüşte Negatif Batı İmgesi' [The Negative Image of the West in Nationalist-Conservative and Islamist Thought], in Uygur Kocabaşoğlu (ed.), Modern Türkiye'de Siyasi Düşünce. Modernleşme ve Batıcılı [Political Thought in Modern Turkey. Modernization and Westernization], vol. 3 (Istanbul: İletişim), pp. 251-268.

Buruma, Ian, Avishai Margalit (2005). Occidentalism. The west in the eyes of its enemies. (London: Penguin Books).

Carrier, James G. (ed.) (1995). Occidentalism. Images of the West (Oxford: Clarendon Press).

Coşkun, Vahap (2016). 'Turkey after 15 of July', 15. July, Serbestiyet website [accessed 15.01.2017]. The url for this website is no longer available.

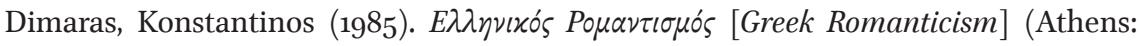
Ermis).

Erdogan, Recep Tayyip (2017). 'Speech by Turkish President R. T. Erdogan to Turkish Governors in Ankara', 9 January, Milliyet, 10 January.

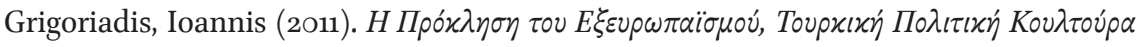

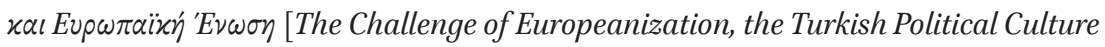
and the European Union] (Athens: Sideris).

Grigoriadis, Ioannis (2013). Instilling religion in Greek and Turkish Nationalism (London: Palgrave Pivot).

Gökalp, Ziya (199o). Türkçülügün Esasları [The Principles of Turkishness](Ankara: Milli Eğitim Yayınları).

Haber 3 (2015). 'Türkler AB'ye girmek istiyor mu?' [Do Turks want to join the EU?], 9 April. http://www.haber3.com/turkler-abye-girmek-istiyor-mu-3305463h.htm [accessed 03.09.2017].

Hanioglu, M. Şükrü (2008). A Brief History of the Late Ottoman Empire (Princeton, Oxford: Princeton University Press).

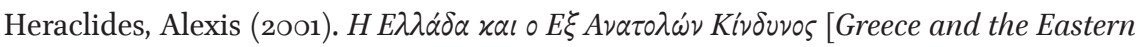
Danger] (Athens: Polis).

Iefimerida (2015). 'Epistoli tis proedrou tou Areiou Pagou se Evrapeous dikastes. $\mathrm{Na}$ ti theli o ellinikos laos' [The letter of the President of the Supreme Court. Let me explain what the Greek people want], 9 July. http://www. iefimerida.gr/ news/216356/epistoli-tis-proedroy-toy-areioy-pagoy-se-eyropaioys-dikastes-na-sasexigiso-ti-thelei-o [accessed 03.09.2017].

Internet Haber (2016). 'Türkiye AB'ye girmek istiyor mu, şok anket' [Does Turkey want to join theEU? shocking polls],16 June.http://www.internethaber.com/turkiye-avrupabirligine-girmek-istiyor-mu-sok-anket-16o6o93h.htm [accessed o3.o9.2017].

Karaiskos, Apostolos (2016). 'Sionismos ke Pagosmiopiisi' [Zionism and Globalisation], 1 October. http://www.xryshaygh.com/ [accessed 17.03.2017]. 
Karaiskos, Thanasis (2016). 'The heartbreaking nightfall of the West', 25 April. https://syrizazante.workpress.com [accessed 17.03.2017].

Katsaros, Dimitris (2014). 'To Islamiko kratos, I Disi ke to KKE' [The Islamic State, the West and the KKE/Greek Communist Party]. http://www.rizopoulospost.com/toislamiko-kratos-h-dysh-kai-to-kke/ [accessed 17.03.2017].

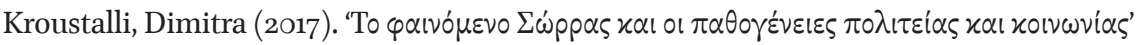
[The Sorras phenomemon and the pathogenesis of state and society], To Vima, 7 January. https://www.tovima.gr/2017/o1/o6/politics/to-fainomeno-swrras-kai-oi-pathogeneies-politeias-kai-koinwnias/ [accessed o3.09.2017].

Leerssen, Joep (2016). 'Imagology. On Invoking Ethnicity to Make Sense of the World', Iberic@l. Revue d'études ibériques et ibéro-américaines, 10, pp. 13-31.

Metallinos, Georgios (1988). Tourkokratia [Turkish Rule] (Athens: Akritas).

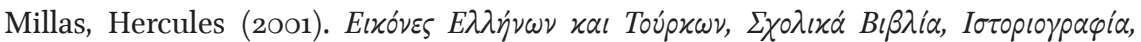

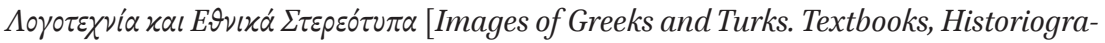
phy, Literary Texts and National Stereotypes] (Athens: Alexandria).

Millas, Hercules (2005a). Türk ve Yunan Romanlarında Öteki ve Kimlik [The Other and Identity in Turkish and Greek Novels] (İstanbul: İletişim).

Millas, Hercules (2005b). 'The Other and Nation Building. The Testimony of Greek and Turkish Novels', in Nedret Kuran-Burçoğlu, Susan Gilson Miller (eds), Representations of the 'Other/s' in the Mediterranean World and Their Impact on the Region (İstanbul: The Issis Press), pp. 141-148.

Millas, Hercules (2006). 'Tourkokratia. History and the Image of Turks in Greek Literature', South European Society and Politics, 11.1, pp. 47-6o.

Millas, Hercules (2008). 'History Writing among the Greeks and Turks. Imagining the Self and the Other', in Stefan Berger, Chris Lorenz (eds), The Contested Nation. Ethnicity, Class, Religion and Gender in National Histories (New York: Palgrave MacMillan), pp. 490-510.

Pew Global Studies survey 2014 (2014). https://www.pewglobal.org/2014/o7/14/globalopposition-to-u-s-surveillance-and-drones-but-limited-harm-to-americas-image/ [accessed 17.03.2017].

Palmos Analysis (2016). 'Dispistoi oi Ellinew apenanti stous evropaikous thesmoous'. [Greeks skeptical vis-à-vis the European institutions], Aixmi.gr, 18 December. https://www.aixmi.gr/index.php/palmos-analysis-dyspistoi-oi-ellhnes-apenantistoys-eyrvpaikoys/

Said, W. Edward (1994). Orientalism (New York: Vintage Book).

Todorova, Maria (2009). Imagining the Balkans (Oxford: Oxford University Press).

ToVima (2016). 'Judges and public prosecutors. Greece is not the economic guinea pig of Europe`, 8 February. https://www.tovima.gr/2016/o2/o8/society/dikastes-kai-eisagget leis-i-ellada-den-einai-to-oikonomiko-peiramatozwo-tis-eyrwpis/ [accessed o3.og.2017]. 
Voria.gr (2016). 'The hypocrisy of the West is ending, the events with Erdogan now begin', 24 July. http://www.voria.gr/article/i-ipokrisia-tis-disis-telioni-ta-gegonoł ta-me-ton-erntogan-tora-archi [accessed 17.03.2017].

Ünüvar, Kerem (2002). 'Ziya Gökalp', in Tanıl Bora (ed.), Modern Türkiye'de Siyasi Düşünce, Milliyetçilik [Political Thought in Modern Turkey, Nationalism], vol. 4 (Istanbul: İletişim), pp. 28-35.

Zürcher, Eric Jan (2004). Modernleşen Türkiye'nin Tarihi [Turkey. A Modern History] (Istanbul: İletişim). 